HELENA PIETRZAK

Uniwersytet Kardynała Stefana Wyszyńskiego w Warszawie

\title{
PRAWO DO ŻYCIA, JEGO NIENARUSZALNOŚĆ I NIEROZPORZĄDZALNOŚĆ. ASPEKTY PRAWNO-KARNE ${ }^{1}$
}

Treść: Wstęp. - 1. Prawnokarna ochrona życia nasciturusa - (krótka geneza). - 2. Aktualne koncepcje (modele) prawnej ochrony życia. - 3. Ochrona nasciturusa $\mathrm{w}$ obowiązującym prawie. -3.1 . Zakres ochrony w prawie karnym. - 3.2. Zakres ochrony dziecka w ustawie o Rzeczniku Praw Dziecka. - 3.3. Cywilnoprawny zakres ochrony nasciturusa. - 4. Koniec życia. - 4.1. Zabójstwo. - 4.2. Zabójstwo eutanatyczne. - Podsumowanie.

\section{Wstęp}

W demokratycznym państwie prawa, opartym na prawidłowo działającej władzy ustawodawczej i wykonawczej, poszanowanie praw człowieka powinno być standardem i wartością normatywną. Wśród tych praw, jako fundament wartości mieści się - prawo do życia, czyli do istnienia ${ }^{2}$ od poczęcia do naturalnej śmierci. Jest prawem naturalnym, wynikającym z przyrodzonej godności, jaką posiada każda istota ludzka, niezależnie od stopnia rozwoju, dojrzałości fizycznej czy emocjonalnej. Prawo to, w znaczeniu konstytucyjnym, należy do katalogu wolności i praw osobistych, jest więc prawem fundamentalnym, któ-

1 Referat został wygłoszony 2 marca 2013 r. na Konferencji Naukowej pt. „Między medycyną a etyką", zorganizowanej przez Katolickie Stowarzyszenie Lekarzy Polskich, Środowisko Inicjatywa oraz Zakon Kawalerów Maltańskich w Wyższym Seminarium Duchownym w Radomiu.

2 B. Kaczmarek, Prawa dziecka poczętego i ich ochrona w Polsce, Acta Universitatis Wratislaviensis no. 2819, Wrocław 2005, s. 129; M. SAFJAN, Prawo wobec ingerencji w naturę ludzkiej prokreacji, Warszawa 1990, s. 318. 
rego nie można się zrzec. Jako prawo podstawowe, gwarantuje możność korzystania przez człowieka z innych przysługujących mu praw i wolności (np. prawa do tożsamości; prawa do prywatności; prawa do nauki).

Stąd też, zadaniem demokratycznego państwa prawa jest kategoryczne uznanie wartości życia ludzkiego „od poczęcia do naturalnej śmierci” w Ustawie Zasadniczej, co zobowiązuje do zapewnienia mu pełnej i bezpośredniej ochrony prawnej przed naruszeniami i uzasadnia użycie w tym celu wszystkich możliwych środków, także prawnokarnych ${ }^{3}$.

Pomimo jednak istoty i wagi znaczenia tego prawa, zakres pełnej i bezwzględnej ochrony prawa do życia nie został do tej pory jednoznacznie określony, szczególnie jeśli chodzi o ustalenie początkowego momentu podlegającego ochronie. Co więcej, w toku rozważań zostanie wykazana powszechna dziś względność tego prawa oraz praktyki pozaustawowe rozporządzania tym prawem.

\section{Prawnokarna ochrona życia nasciturusa - (krótka geneza)}

W czasach starożytnych życie dziecka przed urodzeniem (nasciturusa $)^{4}$ nie podlegało bezpośredniej, prawnokarnej ochronie. Wyższą rangę od życia w okresie prenatalnym miało prawo ojca rodziny do posiadania potomstwa. Podobnie prawo rzymskie traktowało nasciturusa jako część organizmu matki i wraz z nią podlegał władzy ojca rodziny (pater familias). Stopniowe i drobne zmiany zaczęły pojawiać się dopiero ok. 200 r. po Chrystusie i w prawie germańskim (gdzie zabójstwem nazwano każde umyślne przerwanie ciąży).

${ }^{3}$ Szerzej zob. A. GrześKowiak, W trosce o rodzinę, Częstochowa 1996; A. Eser, „Świętość” życia $i$,wartość” życia w historycznoprawnym ujęciu porównawczym, SP $1987 /$ z. 2, s. 145-162.

4 Nasciturus - z j. łac. mający się urodzić (od ,nasci” - rodzić się); prawniczy i powszechnie stosowany termin, używany na określenie dziecka poczętego, a jeszcze nie urodzonego. Szerzej zob. K. KolańCZYK, Prawo rzymskie, Warszawa 1973, s. 164; W. Radwański, Prawo rzymskie. Zarys wykładu wraz z wyborem źródet, Poznań 1992, s. 86 . 
Dopiero w następnych wiekach, pod wpływem chrześcijaństwa, objęto życie dziecka poczętego samoistną ochroną prawnokarną. Potępienie moralne ze strony Kościoła ${ }^{5}$ wpłynęło na prawo świeckie, które zaczęło traktować przerwanie ciąży jako zabójstwo osoby ludzkiej. Jednak rozważania filozoficzno-teologiczne w kwestii „uduchowienia" (trwające aż do końca XVIII w.), a więc ustalenia że dusza łączy się $\mathrm{z}$ ciałem dopiero po kilku tygodniach od poczęcia, dotknęły również Kościół, który chociaż nadal potępiał aborcję, to jednak w taką dyskusję się włączył $1^{6}$. Dyskusja ta znalazła swoje odzwierciedlenie w prawie karnym. Stąd też, wydana przez cesarza Karola V w 1532 r. Constitutio Criminalis Carolina uwzględniła w katalogu zabójstw (obok dzieciobójstwa i porzucenia noworodka) - także spędzenie płodu, zagrożone karą śmierci (dla mężczyzn przez powieszenie; dla kobiet przez utopienie). W kodeksie tym przyjęto jednak kryterium „duchowe” i wyłączono z ochrony karnej tzw. „potworka”, któremu odmawiano posiadania duszy.

Kodeksy karne z XVII i XVIII w. utrzymały kwalifikację zabójstwa spędzenia płodu „ożywionego” i „nieożywionego”. Pierwszy kodeks karny, w którym odstąpiono od kryterium rozwoju płodu, został ogłoszony przez cesarza Józefa II w Austrii (1787 r.). Podobnie uczyniły inne kraje europejskie. Stąd też, kodeksy karne XIX-wieczne opierały się na jednolitym modelu ochrony życia dziecka poczętego. Ponowny zwrot nastąpił na przełomie XIX i XX w. Pojawiły się tendencje do liberalizacji i łagodzenia sankcji za usunięcie ciąży. Zaczęto przeciwstawiać życie nasciturusa innym dobrom chronionym przez prawo

5 Warto dodać, że pierwsze lokalne synody nakładały na kobietę ekskomunikę (synod w Elwirze z IV w. przewidywał dożywotnią ekskomunikę; czasową ekskomunikę przewidywał synod w Ancyrze z 314 r. na okres 10 lat; synod w Leryndze z 546 r. ograniczył ją do 7 lat).

${ }^{6}$ Dekret Gracjana (zbiór prawa kanonicznego) rozróżniał spędzenie płodu przed i po „uduchowieniu”. Dopiero średniowieczne księgi pokutne (Libri poenitentialis) złagodziły sankcje kościelne wobec umyślnego sprawcy usunięcia ciąży (w pierwszych 40 dniach od poczęcia). Także św. Tomasz uwzględniał podział okresu prenatalnego na 2 fazy, a jego interpretatorzy wskazywali, że połączenie duszy z ciałem następuje w 40 dni od poczęcia dla chłopców, a w 80 dla dziewczynek. 
np. interesom matki. Powszechnie z kodeksów karnych wyłączono bezwzględną prawnokarną ochronę życia płodu. Prawo to stało się względnym, podlegało stałym ograniczeniom, zależnym od tzw. wskazań do przerwania ciąży (medycznym czy stanu wyższej konieczności, gdy ciąża zagrażała życiu matki; eugenicznym, z powodu wad fizycznych czy psychicznych płodu; kryminalnym, gdy ciąża była wynikiem np. gwałtu). Jednak najszerszy zakres w modelu wskazań, stanowiły względy społeczne lub społeczno-osobiste (trudna sytuacja materialna lub osobista matki dziecka) zezwalając na aborcję „na żądanie”.

Po raz pierwszy ustawodawca kodeksu karnego ZSRR z 1922 r. całkowicie odrzucił bezpośrednią ochronę życia nasciturusa, traktując płód jako część organizmu matki. Za przedmiot prawnokarnej ochrony przyjęto jedynie „bezpieczeństwo życia i zdrowia kobiety oraz swobodę dysponowania płodem"7. W krótkim odstępie czasowym po II wojnie światowej (w 1954 r.) nastąpiła ponowna dekryminalizacja aborcji, z tym że śladami ZSRR poszły inne kraje demokracji ludowej szeroko legalizujące aborcję (także Polska ustawą z 1956 r.). Pojawiły się także skrajne rozwiązania np. w Chinach, gdzie aborcję potraktowano jako „ważny element polityki ludnościowej”.

W doktrynie prawa zwraca się uwagę na wpływ II wojny światowej i prawa międzynarodowego (m.in. Powszechnej Deklaracji Praw Człowieka, Międzynarodowego Paktu Praw Obywatelskich i Politycznych, Deklaracji Podstawowych Praw i Wolności) na wstrzymanie legalizacji aborcji, jednak jest to czas krótki - w krajach komunistycznych do połowy lat 50-tych, w krajach zachodnich do lat 60-tych i 70-tych.

Konkludując wątek genezy, warto podkreślić, że już w latach 50-tych XX w. zaczęto rezygnować z prawa karnego dla bezwzględnej ochrony prawa człowieka do życia. Prawu karnemu pozostawiono jedynie ochronę życia człowieka już urodzonego, pozbawiając go funkcji

${ }^{7}$ E. ZIELIŃSKA, Oceny prawnokarne przerywania ciąży. Studium porównawcze, Warszawa 1986, s. 120 i n.; A. GRZEŚKOWIAK, Ochrona życia ludzkiego na tle rozwiazań nowego kodeksu karnego, Ethos 1999, nr 45-46, s. 261-275; J. ŚLiwowsKi, Kodeks Karzacy Królestwa Polskiego (1918 r.). Historia jego powstania i próba krytycznej analizy, Warszawa 1923; M. TARNAWSKI, Jeszcze na temat prawnokarnej ochrony życia ludzkiego, NP 1976/ z. 7-8, s. 1151-1155. 
ochrony wobec dziecka poczętego. Wyłączając pełną ochronę życia z kodeksów karnych, przekazano te uprawnienia ustawom specjalnym (aborcyjnym), w których prawo do życia nabrało charakteru względnego, zależnego od sytuacji, w których pozbawienie życia człowieka nie powoduje konsekwencji karnych.

Ustawy te dość powszechnie zastąpiły prawną ochronę życia i kreują prawną fikcję ochrony życia dla ukrycia wymowy znaczeniowej pojęcia: zabójstwo, czy przestępstwo. Podmiot, który winien być chroniony jest uzależniony od dozwolonej aborcji, a zakres ochrony jego życia jest odwrotnie proporcjonalny do zakresu legalizacji aborcji. Powszechne dziś w legislacji fikcje prawne, różne definicje legalne (ustawowe) określonego wyrażenia, czy wręcz celowe luki w prawie dają przyzwolenie na łamanie, czy omijanie prawa. Niejednokrotnie mają też inny, ukryty cel, minimalizują powszechną negację i odczucia społeczne. Manipulując definicją ,,człowiek w fazie prenatalnej”, odejmując cech podmiotowych, ustawodawca przełamuje tabu, czy wręcz nakazy prawa karnego, a umniejszając cech podmiotu, człowiek staje się przedmiotem. Stąd też, jego prawo do życia nabiera w praktyce jedynie charakteru względnego, którym dysponują i rozporządzają inne osoby - najczęściej silniejsze.

\section{Aktualne koncepcje (modele) prawnej ochrony życia}

Współczesne systemy prawne, eliminując pełną i bezwzględną ochronę życia z kodeksów karnych, ukształtowały trzy modele prawa do życia nasciturusa w jego prenatalnej fazie rozwoju.

Pierwszy, najszerszy, (rzadko występuje współcześnie) ${ }^{8}$ obejmuje pełną i bezpośrednią ochroną życie dziecka poczętego. Uznaje, że wartość życia i zdrowia każdej istoty ludzkiej jest niezależna od jego okresu rozwoju. Stąd też, śmierć dziecka w koncepcji tej jest traktowana

${ }^{8}$ Kraje, które przyjęły ten model, gwarantują pełne i integralne poszanowanie życia ludzkiego. Należą do nich w Europie: (Irlandia, Andora, Malta, San Marino) w Afryce: (Egipt, Dżibuti, Republika Środkowoafrykańska, Mauritius) w Azji: (Bhutan, Filipiny, Nepal) w Ameryce Łacińskiej: (Dominikana, Chile, Honduras, Kolumbia). Szerzej zob. K. WiaK, Ochrona dziecka poczętego w polskim prawie karnym, Lublin 2001, s. 36 . 
jako przestępstwo powszechne, którego podmiotem może być również matka. Prawodawca łagodzi rygoryzm sankcji karnej w sytuacji wyłączenia umyślności spowodowania śmierci dziecka w wyniku działania w stanie wyższej konieczności.

Drugi, model wskazań, występuje w większości krajów - także w Polsce, przewiduje dookreślone ustawowo wyjątki od pełnej ochrony życia ludzkiego w jego prenatalnej fazie. W tej koncepcji prawo do życia i jego kontynuowanie uzależnione jest od prymatu innych wartości. Ustawodawca określa szczególne okoliczności (wskazania), wyłączające bezprawność i karalność czynu sprawcy. Katalog wskazań najczęściej jest pozornie zamknięty, gdyż zawiera w sobie sformułowania nazywane powszechnie w prawie ,zwrotami niedookreślonymi”, które w zależności od stanu faktycznego mogą przybrać inne znaczenie, często są też nadinterpretowane (w wyniku zastosowania wykładni rozszerzającej). Należą do nich: wskazania medyczne (gdy ciąża stanowi zagrożenie życia i zdrowia matki dziecka); wskazania eugeniczne (ciężkie i nieodwracalne uszkodzenie płodu) i wskazania kryminalne (gdy ciąża jest wynikiem czynu zabronionego). Zakres wskazań był sukcesywnie poszerzany, obarczony jest też genezą orzeczeń niemieckiego Sądu Rzeszy z 1927 r. i późniejszą grozą nadużyć wobec wskazań eugenicznych ukierunkowanych na ,interesy państwa i rasy”.

Ostatni, trzeci model wyznaczający zakres poszanowania prawa do życia, to model terminowy (nazywany także ,aborcją na żądanie”). Status prawny nasciturusa w tej koncepcji jest niedookreślony, nie jest tożsamy z osobą już narodzoną. Co więcej, status podmiotu prawnego, podlegającego ochronie uzyskuje dopiero po określonym terminie wskazanym w ustawie (np. od początku drugiego trymestru; lub też gdy płód osiągnie zdolność do samodzielnego życia poza organizmem matki). Dość często, ustawodawca po wyczerpaniu terminu ustawowego, sięga ponadto po kryterium wskazań (najczęściej wymienione wyżej - wskazania medyczne i eugeniczne). W tym zakresie matka dziecka jest wyłącznym dysponentem jego życia, a powody aborcji są z punktu widzenia prawa karnego - obojętne 9 .

${ }^{9}$ Model terminowy przewidziany jest w następujących krajach: Dania, Austria, 


\section{Ochrona nasciturusa w obowiązującym prawie}

Zasadnicze zmiany legislacyjne, które miały miejsce w latach 1993-2000 ukształtowały dość skomplikowany stan prawny w kontekście prawnokarnej ochrony dziecka. Przyjęte w art. 38 Konstytucji RP ogólne ramy ochrony, zapewniające każdemu człowiekowi prawną ochronę życia, zderzyły się także z orzecznictwem Trybunału Konstytucyjnego. Trybunał w jednym $\mathrm{z}$ orzeczeń wydanym przed wejściem w życie obecnej Konstytucji, dość jednoznacznie odniósł się do braku w przepisach nakazu prawnej ochrony dziecka poczętego od poczęcia do naturalnej śmierci. Stwierdzil, że „ochrona prawna życia rozpoczyna się już od poczęcia każdej istoty ludzkiej”, a „wartość życia ludzkiego jako dobra chronionego konstytucyjnie nie może być zależna od etapu rozwoju" 10 .

\subsection{Zakres ochrony w prawie karnym}

Ustawodawca Kodeksu karnego z 6 czerwca 1997 r. ${ }^{11}$ penalizuje zachowania polegające na pozbawieniu życia innego człowieka. Do katalogu przestępstw (ściganych z urzędu) w odniesieniu do początkowego etapu życia człowieka należy:

- zabójstwo noworodka (dzieciobójstwo) - art. 149 k.k.;

- przerwanie ciąży (aborcja) - art. 152 k.k. z naruszeniem ustawy z 1993 r. $^{12}$

- przerwanie ciąży bez zgody - art. 153 k.k.

Grecja, Holandia, Norwegia, Szwecja, Mongolia, Singapur, Turcja, Wietnam, Chiny, USA, Kanada, Kuba, Tunezja. Niemcy określiły termin do 12 tygodni.

${ }^{10}$ Orzeczenie Trybunału Konstytucyjnego z dnia 28 maja 1997 r., K 26/96, OTK 1997, nr 2, poz. 19. Trybunał Konstytucyjny w orzeczeniu z 28 maja 1997 r. uznał także za niezgodne z Konstytucyjną zasadą demokratycznego państwa prawa przepisy ustawy legalizujące aborcję ze względu na ciężkie warunki życiowe lub trudną sytuację osobistą kobiety.

${ }^{11}$ Ustawa z dnia 6 czerwca 1997 roku - Kodeks karny (Dz. U. z 1997 r., Nr 88, poz. 553 z późn. zm.); dalej jako: k.k.

${ }^{12}$ Ustawa z dnia 7 stycznia 1993 roku o planowaniu rodziny, ochronie płodu ludzkiego i warunkach dopuszczalności przerywania ciąży (Dz. U. z 1993 r., Nr 17, poz. $78 \mathrm{z}$ późn. zm.). 
- uszkodzenie ciała dziecka w fazie prenatalnej - art. 157 a k.k.

Pierwsze z przestępstw - dzieciobójstwo (art. 149 k.k. ${ }^{13}$ ), przedmiotem ochrony obejmuje ,życie w okresie porodu”, którego sprawcą może być tylko matka. Stanowi więc przestępstwo o charakterze indywidualnym. W orzecznictwie i doktrynie prawa karnego ma ono wymiar uprzywilejowanego typu przestępstwa zabójstwa, z uwagi na okoliczności psychofizyczne matki towarzyszące porodowi (w szczególności wstrząs porodowy obejmujący okres porodu i stan bezpośrednio po nim). Stąd rozpiętość sankcji karnej (kara pozbawienia wolności od 3 miesięcy do 5 lat). Cezurę kwalifikacji pomiędzy przestępstwem dzieciobójstwa a przerwaniem ciąży stanowi kryterium położnicze (początek akcji porodowej).

Drugie przestępstwo - przerwanie ciąży (aborcja) - art. 152 k.k. ${ }^{14}$, chociaż ma na celu ochronę życia w fazie prenatalnej, to jednak zachowanie sprawcy przestępstwa zostało zredukowane do naruszeń ustawy z 1993 r. Ustawa ta uwzględniając model wskazań wyłącza odpowiedzialność kobiety, u której przerwano ciążę i lekarza w przypadku, gdy: - ciąża stanowi zagrożenie dla życia lub zdrowia kobiety ciężarnej (przesłanka medyczna);

- badania prenatalne lub inne przesłanki medyczne wskazują na duże prawdopodobieństwo ciężkiego i nieodwracalnego upośledzenia płodu albo nieuleczalnej choroby zagrażającej jego życiu (przesłanka eugeniczna - dopuszczalna do chwili osiągnięcia przez płód zdolności do samodzielnego życia poza organizmem matki);

- zachodzi uzasadnione podejrzenie, że ciąża powstała w wyniku czynu zabronionego (przesłanka kryminalna - dopuszczalna do 12 tygodnia ciąży).

${ }^{13}$ Art. 149. „Matka, która zabija dziecko w okresie porodu pod wpływem jego przebiegu podlega karze pozbawienia wolności od 3 miesięcy do lat 5".

${ }^{14}$ Art. 152. $§ 1$. Kto za zgodą kobiety przerywa jej ciążę z naruszeniem przepisów ustawy, podlega karze pozbawienia wolności do lat 3 .

$\S 2$. Tej samej karze podlega, kto udziela kobiecie ciężarnej pomocy w przerwaniu ciąży z naruszeniem przepisów ustawy lub ją do tego nakłania.

$\S 3$. Kto dopuszcza się czynu określonego w $§ 1$ lub 2, gdy dziecko poczęte osiągnęło zdolność do samodzielnego życia poza organizmem kobiety ciężarnej, podlega karze pozbawienia wolności od 6 miesięcy do lat 8 . 
Ustawodawca oprócz powyższych podstaw, wymaga pisemnej zgody kobiety ciężarnej, bądź jej przedstawiciela ustawowego.

Z uwagi na uzyskanie w wieku 13 lat - ograniczonej zdolności do czynności prawnych, w imieniu małoletniej poniżej tego wieku zgodę wyraża jej przedstawiciel ustawowy (rodzic lub opiekun prawny, jednak zawsze za zgodą sądu opiekuńczego przed którym małoletnia wyraża swoją opinię). Natomiast osoba 13-letnia ma prawo wyrazić swoją wolę, jednak dla jej ważności musi być ona potwierdzona zgodą przedstawiciela.

Ostatnie dwa przestępstwa przeciwko życiu i zdrowiu nasciturusa (przerwanie ciąży bez zgody ${ }^{15}$ oraz uszkodzenie ciała dziecka w fazie prenatalnej ${ }^{16}$ ), stanowią typ przestępstwa kwalifikowanego ${ }^{17}$. Ustawodawca penalizuje przerwanie ciąży wbrew woli kobiety, ujmując w zakres ochrony również prawo kobiety do urodzenia dziecka. Zachowanie sprawcy, polegające na użyciu przemocy, groźby bezprawnej lub

${ }^{15}$ Art. 153. § 1. Kto stosując przemoc wobec kobiety ciężarnej lub w inny sposób bez jej zgody przerywa ciążę albo przemocą, groźbą bezprawną lub podstępem doprowadza kobietę ciężarną do przerwania ciąży, podlega karze pozbawienia wolności od 6 miesięcy do lat 8 .

$\S 2$. Kto dopuszcza się czynu określonego w $§ 1$, gdy dziecko poczęte osiągnęło zdolność do samodzielnego życia poza organizmem kobiety ciężarnej, podlega karze pozbawienia wolności od roku do lat 10 .

${ }^{16}$ Art. 157 a. $§ 1$. Kto powoduje uszkodzenie ciała dziecka poczętego lub rozstrój zdrowia zagrażający jego życiu, podlega grzywnie, karze ograniczenia wolności albo pozbawienia wolności do lat 2 .

$\S 2$. Nie popełnia przestępstwa lekarz, jeżeli uszkodzenie ciała lub rozstrój zdrowia dziecka poczętego są następstwem działań leczniczych, koniecznych dla uchylenia niebezpieczeństwa grożącego zdrowiu lub życiu kobiety ciężarnej albo dziecka poczętego.

$\S 3$. Nie podlega karze matka dziecka poczętego, która dopuszcza się czynu określonego w $\S 1$.

${ }^{17}$ Podkreślenia wymaga fakt, że ustawodawca kodeksowy stosując w art. 152-154 k.k. zwrot „kto przerywa ciążę” eliminuje tym samym możność ochrony prawnokarnej życie ludzkie powstałe w wyniku inseminacji homo i heterologicznej, czy też metodą in vitro. Jest to o tyle istotne, że z dniem 13 czerwca 2009 r. do Kodeksu rodzinnego i opiekuńczego, wszedł zapis obejmujący „zabieg medyczny” potwierdzający prawa filiacyjne (pochodzenie od męża matki). Dlatego też, w 1999 r. dodano do Kodeksu karnego art. 157 a, obejmujący zabiegi in vitro. 
podstępu - narusza życie nasciturusa oraz wolność kobiety, dlatego też nie podlega w ogóle ocenie bezprawność tego czynu zgodnie z ustawą z 1993 r. Z uwagi na powszechność tego przestępstwa w zakresie podmiotów odpowiedzialnych może znaleźć się również lekarz, którego stan świadomości będzie odpowiednio proporcjonalny do sankcji karnej. Obostrzenie odpowiedzialności karnej w tym typie przestępstwa wzrasta wraz z poważnym zagrożeniem dla zdrowia kobiety w sytuacji przerwania zaawansowanej ciąży.

Stąd też, z podobnym typem przestępstwa mamy do czynienia, gdy następstwem czynu sprawcy jest śmierć kobiety ciężarnej (art. 154 k.k. ${ }^{18}$ ). Szczególnie jeśli sprawca przestępstwa, przewidywał lub mógł przewidzieć następstwo w postaci śmierci kobiety.

Ostatni typ przestępstwa - uszkodzenie ciała dziecka w fazie prenatalnej, wprowadzono do Kodeksu karnego ustawą z 8 lipca 1999 r. (157 a k.k.) na skutek interwencji Trybunału Konstytucyjnego ${ }^{19}$. Bezpośrednim przedmiotem ochrony objęte jest zdrowie i prawidłowy rozwój dziecka poczętego, niezależnie od środowiska egzystowania podmiotu prawa (także in vitro). Ustawodawca wyłącza odpowiedzialność karną lekarza, jeśli uszkodzenie ciała lub rozstrój zdrowia dziecka poczętego jest następstwem działań leczniczych, koniecznych dla ratowania życia lub zdrowia dziecka albo matki. Spod odpowiedzialności karnej wyłączona jest również matka dziecka. W odniesieniu do tej normy widoczna jest niekonsekwencja ustawodawcy karnego, który przerwanie ciąży wbrew warunkom ustawy z 1993 r. dokonane przez samą

${ }^{18}$ Art. 154. § 1. Jeżeli następstwem czynu określonego w art. $152 \S 1$ lub 2 jest śmierć kobiety ciężarnej, sprawca podlega karze pozbawienia wolności od roku do lat 10 .

$\S$ 2. Jeżeli następstwem czynu określonego w art. $152 \S 3$ lub w art. 153 jest śmierć kobiety ciężarnej, sprawca podlega karze pozbawienia wolności od lat 2 do 12.

${ }^{19}$ Obowiązujący w dawnym Kodeksie karnym art. 23b ustanawiał zakaz naruszania integralności cielesnej płodu lub zakłócania procesów rozwojowych poza określonymi wypadkami. Został on jednak skreślony przez nowelizację ustawy z 1993 r. (z dniem z 30 sierpnia 1996 r.). Spowodowało to brak ochrony płodu przed eksperymentami do czasu wejścia w życie nowej ustawy O zawodzie lekarza, tj. do dnia 27 września 1997 roku (art. 26 ust. 1 i 2 tej ustawy). W konsekwencji orzeczenia Trybunału Konstytucyjnego ustawą z 8 lipca 1999 r. został wprowadzony do kodeksu karnego art. 157a. 
kobietę ciężarną uznaje za legalne, natomiast spowodowanie uszkodzenie ciała lub rozstrój zdrowia nascitutusa uznaje za bezprawne, chociaż niekaralne.

\subsection{Zakres ochrony dziecka w ustawie o Rzeczniku Praw Dziecka}

Dla ochrony praw dziecka ustawodawca polski powołał w $2000 \mathrm{r}$. Rzecznika Praw Dziecka ${ }^{20}$, który zgodnie z art. 3 ,podejmuje działania mające na celu zapewnienie dziecku pełnego i harmonijnego rozwoju, z poszanowaniem jego godności i podmiotowości”, a działając na rzecz „ochrony praw dziecka”, jest zobowiązany w szczególności do ochrony „prawa do życia i ochrony zdrowia”. Odwołując się do zapisu art. 2 „dzieckiem jest każda istota ludzka od poczęcia do pełnoletniości”.

Niestety chociaż kompetencje Rzecznika jasno określa art. 2 i 3 ustawy, to jednak zapisy powyższe są w praktyce jedynie martwą literą, co zresztą sugerują pytania i odpowiedzi zawarte na stronie internetowej Rzecznika. W odpowiedzi na pytanie: „Co to są prawa dziecka?” - pada właściwa odpowiedź, że „najważniejszym, naturalnym prawem człowieka jest prawo do życia”. Dalej jednak Rzecznik pisze „Dzieci posiadają szczególne prawa. Aktualizacja ich człowieczeństwa przebiega bowiem w szczególny sposób".

Nie budzi zatem wątpliwości, że chociaż Rzecznik Praw Dziecka wielokrotnie interweniuje w sprawie: zagrożenia zdrowia i życia dziecka (ponad 500 spraw), to jednak próżno szukać interwencji podjętych wobec samego prawa do życia nasciturusa. W znanych sprawach, których matką była małoletnia, Rzecznik miał podwójną rolę do odegrania, ale ich się w ogóle nie podjął. Z kolei tam, gdzie Rzecznik starał się wykazać, podjął interwencję za późno - po śmierci dzieci (znana z mediów sprawa w Hipolitowie). Nie dziwi zatem negatywna opinia wielu środowisk w zakresie powstrzymywania się Rzecznika Prawa Dziecka w czynne jego angażowanie się w sprawy naruszające fundamentalne prawo dziecka nienarodzonego do życia. Opis sprawy po fakcie, kiedy dziecko życie już straciło, nie jest interwencją - tylko diagnozą, której dokonuje wymierzając kary sąd na wniosek prokuratora.

${ }^{20}$ Dz.U. Nr 6, poz. 69. 


\subsection{Cywilnoprawny zakres ochrony nasciturusa}

Ustawodawca prawa cywilnego przyznaje każdemu człowiekowi zdolność prawną (czyli zdolność do bycia podmiotem praw i obowiązków) dopiero od chwili urodzenia (art. $8 \S 1$ k.c. ${ }^{21}$ ). Także najwcześniej, bo dopiero z momentem urodzenia ustawodawca polski przyznaje rodzicom dziecka ${ }^{22}$ - władzę rodzicielskąa ${ }^{23}$.

Przed urodzeniem się dziecka, atrybuty władzy rodzicielskiej nie mogą być w pełni realizowane z kilku powodów. Po pierwsze, z braku prawnej możliwości ustalenia pochodzenia dziecka (za wyjątkiem domniemania pochodzenia z małżeństwa). Po drugie, z ewentualnego zagrożenia życia nienarodzonego dziecka, działaniami podjętymi przez jego rodziców w kwestii aborcji, które to działanie nie można w żadnym razie zaliczyć do treści władzy rodzicielskiej.

Stąd też, w okresie prenatalnym, dziecko nie jest powszechnie reprezentowane. Jako realizację ochrony praw nienarodzonego, prawodawca przyjął możność powołania ${ }^{24}$ kuratora ventris ${ }^{25}$, którego celem jest dobro nasciturusa, wzmocnione tzw. interesem społecznym (art.

${ }^{21}$ Urodzenie, od którego rozpoczyna się zdolność prawna człowieka, następuje na skutek naturalnego lub sztucznego odłączenia dziecka od ciała matki. Nie jest konieczne przerwanie (przecięcie pępowiny). Zgodnie z art. 9 k.c. w razie urodzenia się dziecka domniemywa się, że przyszło ono na świat żywe. Zob. art. 9 ustawy z dnia 23 kwietnia 1964 r. Kodeks cywilny, Dz. U. Nr 16, poz. 93 z późn. zm.

${ }^{22}$ Jest to jeden $\mathrm{z}$ początkowych momentów powstania władzy rodzicielskiej z mocy prawa w relacji dziecko - rodzice. Ustawa z dnia 25 lutego 1964 r. Kodeks rodzinny i opiekuńczy, Dz.U. Nr 9, poz. 59, z późn. zm.; dalej jako: k.r.o.

${ }^{23}$ Prawodawca w całokształcie uregulowań k.r.o., także w art. 92 (chociaż nie wprost) przyjął zasadę, że władza rodzicielska powstaje ex lege z chwilą urodzenia się dziecka.

${ }^{24}$ Kuratora dla nasciturusa ustanawia się z urzędu, gdy zaistnieją prawne podstawy, lub na wniosek oznaczonej osoby (art. 506 i 570 k.p.c.). Ustawa z dnia 17 listopada 1964 r. Kodeks postępowania cywilnego, Dz.U. Nr 43, poz. 296 z późn. zm.

${ }^{25}$ Kuratorem ventris może być ustanowiony jeden z rodziców, jednakże tylko wówczas, jeśli między nim a dzieckiem nie zachodzi sprzeczność interesów. W sytuacji, gdy zachodzi taka sprzeczność, kurator powinien zostać ustanowiony spośród krewnych (z uwagi na więzi uczuciowe i gwarancję realizacji dobra dziecka) lub innych osób bliskich (uwzględnia się tutaj więzi przyjaźni z rodzicami, znajomości, czy też życzliwości). Taką osobę mogą wskazać również rodzice. 
182 k.r.o.). Dobro to dookreślono jako ,strzeżenie przyszłych praw dziecka", czyli tych praw, które będą przysługiwać dziecku od chwili urodzenia. Musi jednak zachodzić realna podstawa zagrożenia naruszenia tych praw (np. pominięcie dziecka poczętego, jako potencjalnego spadkobiercy ${ }^{26}$; dochodzenie w przyszłości roszczeń odszkodowawczych - art. 310 k.c.). W zakresie karnoprawnym za ,realne zagrożenie praw dziecka" można uznać ewentualne działania, podejmowane ze strony osób bliskich, bądź osób trzecich, ukierunkowane na możność przerwania ciąży. Podobnie należy traktować wyeliminowanie takich działań leczniczych, które mogą spowodować - opisane wcześniej przestępstwa: uszkodzenie ciała dziecka poczętego lub rozstrój zdrowia zagrażający jego życiu (z art. 157a k.k.). Przedmiotem ochrony, podejmowanym przez kuratora ventris, jest zdrowie i życie dziecka poczętego, rozwijające się w łonie matki. Dla ustawodawcy Kodeksu karnego istotny jest bezpośredni przedmiot ochrony, natomiast pośrednio norma ta obejmuje - prawo matki dziecka (lub rodziców) do prawidłowego rozwoju dziecka. Stąd też, z chwilą urodzenia dziecko (za pomocą przedstawiciela ustawowego) może żądać naprawienia szkód prenatalnych ${ }^{27}$ doznanych przed urodzeniem (art. $446^{1}$ k.c. $)^{28}$.

${ }^{26}$ Prawa spadkowe zostały nasciturusowi najwcześniej i najpełniej zagwarantowane. Co więcej, unormowania jego pozycji w prawie spadkowym stanowią punkt wyjścia i kierunek do określenia ogólnej pozycji nienarodzonego w kwestii stanowienia przepisów prawnych i uznania jego pozycji w orzecznictwie sądowym. Stąd też, zgodnie z art. 927 § 2 k.c. dziecko w chwili otwarcia spadku (śmierci spadkodawcy) już poczęte, może być spadkobiercą, jeżeli urodzi się żywe (podobnie należy odnieść to prawo do zapisu). Norma ta umożliwia spadkobranie przez dziecko już poczęte w chwili śmierci spadkodawcy, nie tylko po swoim ojcu, ale i po matce (rzadszy przypadek) oraz innych spadkodawcach ustawowych i testamentowych. Ustawodawca uwzględniając nienarodzonego w katalogu spadkobierców, bierze pod uwagę warunek „żywego urodzenia”. Stad też, poprzez instytucję podstawienia (substytucję) otwiera możliwość powołania innego spadkobiercę na wypadek, gdyby dziecko poczęte urodziło się martwe (art. 963 k.c.).

${ }^{27} \mathrm{Za}$,szkodę prenatalną" należy uznać wszystkie zdarzenia, które miały miejsce przed urodzeniem dziecka, w wyniku których doszło do rozstroju zdrowia i zagrożenia życia.

${ }^{28}$ Z. BanaszczyK, Kodeks cywilny. T. 1. Komentarz, Warszawa 2004, s. 1137. 
Prawodawca uwzględniając nienarodzonego w katalogu uprawnionych, bierze pod uwagę warunek ,żywego urodzenia" ${ }^{29}$, potwierdzając tym samym warunkową zdolność prawną i procesową dziecka poczętego. Chwila urodzenia się dziecka determinuje również ustanie kurateli ventris z mocy prawa, a więc koniec ${ }^{30}$.

W doktrynie prawa podkreśla się wagę i zasadność ustanowienia kuratora ventris także w samych unormowaniach prawa materialne$\mathrm{go}^{31}$. Podnoszone są jednak zarzuty dotyczące częstego pomijania powołania kuratora dziecka poczętego dla ochrony jego praw obecnych i podstawowych, a więc prawa do życia. Jest to o tyle istotne, że często przedmiotowa ochrona łączy się z ochroną zdrowia również samej matki (np. w kwestii właściwego odżywiania, gdy nadużywa ona alkoholu, czy narkotyków i o to zdrowie nie jest w stanie sama zadbać). Coraz częściej w literaturze pojawia się pogląd o zmianę władzy rodzicielskiej, poprzez ustanowienie jej momentu początkowego na moment poczęcia. Sama zaś kuratela ventris, znajdowałaby swoje uzasadnienie w przypadku wyraźnej kolizji między interesem dziecka poczętego a interesem jego rodziców (bądź jednego rodzica) ${ }^{32}$.

${ }^{29}$ Warunek ,żywych narodzin” jest kompromisem pomiędzy ideą ochrony nienarodzonego a koncepcją przyznającą podmiotowość prawną (zdolność prawną - art. 8 § 1 k.c.) dopiero człowiekowi już urodzonemu. Należy jednak pamiętać, że owa ochrona nie jest realizowana dopiero ex post po ,żywym urodzeniu”. Normy wskazujące na możliwość powołania kuratora ventris dobitnie świadczą o tym, że ochrona występuje jeszcze w życiu prenatalnym. Normy te, co prawda nie expressis verbis, jednak zrównują status dziecka poczętego z tym jaki posiada już dziecko urodzone (natus). Wątpliwość polega jedynie na domniemaniu zawartym w art. 8 \$ 1 k.c. - ,żywego urodzenia”.

${ }^{30}$ Zgodnie $\mathrm{z}$ art. 180 k.r.o. kuratela ustaje $\mathrm{z}$ mocy prawa - z chwilą zakończenia sprawy, do której była ustanowiona, albo poprzez jej uchylenie przez organ ustanawiający. Czas trwania kurateli ventris jest zdeterminowany - chwilą urodzenia się dziecka. Moment jej ustania może być również wcześniejszy w przypadku śmierci dziecka przed jego urodzeniem lub też śmierci samego kuratora. Sąd może również na żądanie kuratora lub z urzędu - zwolnić kuratora z pełnionej funkcji (art. 169 k.r.o.) i powierzyć obowiązki innemu kuratorowi.

${ }^{31}$ H. Pietrzak, Prawo do życia pod nadzorem kuratora ventris, Człowiek-Rodzina-Prawo 2012, nr 9, s. 6. / http://www.kul.pl/czlowiek-rodzina-prawo,art_35897.html/.

${ }^{32}$ Szerzej zob. H. PietrzaK, Curator ventris dla nasciturusa, Studia nad Rodziną 2011(28-29) nr 1-2, s. 145-164. 


\section{Koniec życia}

Drugim aspektem prawnym dotyczącym prawa do życia - jest wskazanie granic czasowych życia ludzkiego. Te granice zostały określone przez śmierć, rozumianą w prawie cywilnym jako „koniec bytu osoby fizycznej". Z tą różnicą, że prawodawca oprócz śmierci w znaczeniu biologicznym, uwzględnia również prawne możliwości uznania osoby za zmarłą w sytuacji nadzwyczajnej, gdy nie ma ciała, a osoba zaginęła. Należą do nich: uznanie za zmarłego i stwierdzenie zgonu ${ }^{33}$.

Poza aspektem cywilnym, prawo karne penalizuje zachowania polegające na pozbawieniu życia innego człowieka, uznając za przestępstwo: m.in. zabójstwo; zabójstwo eutanatyczne, samobójstwo oraz nieumyślne spowodowanie śmierci. Z katalogu kar, które funkcjonowały wcześniej dość powszechnie usunięto - karę śmierci, której w Polsce nie wykonuje się już od 1988 r.

\subsection{Zabójstwo}

Powszechne w prawie karnym przestępstwo zabójstwa (art. 148 k.k. ${ }^{34}$ ), którego sprawcą może być każda osoba - polega na zabójstwie

${ }^{33}$ Zob. T. MARCInKowski, Z zagadnień tanatologii $w$ aspekcie sadowo-lekarskim, NP 1970, nr 7-8, s. 1136; M. SoŚNIAK, Śmierć (problematyka lekarsko-prawna, PiP 1970, nr 3-4, s. 506; A. SzPunar, Prawo cywilne. Część ogólna, Warszawa 1967, s. 158; A. Wolter, J. Ignatowicz, K. Stefaniuk, Prawo cywilne. Zarys części ogólnej, Warszawa 2001, s. 193-198.

${ }^{34}$ Art. 148 . $§ 1$. Kto zabija człowieka, podlega karze pozbawienia wolności na czas nie krótszy od lat 8 , karze 25 lat pozbawienia wolności albo karze dożywotniego pozbawienia wolności.

$\S 2$. Kto zabija człowieka:

1) ze szczególnym okrucieństwem,

2) w związku z wzięciem zakładnika, zgwałceniem albo rozbojem,

3) w wyniku motywacji zasługującej na szczególne potępienie,

4) z użyciem materiałów wybuchowych, podlega karze pozbawienia wolności na czas nie krótszy od lat 12, karze 25 lat pozbawienia wolności albo karze dożywotniego pozbawienia wolności.

$\S 3$. Karze określonej w $§ 2$ podlega, kto jednym czynem zabija więcej niż jedną osobę lub był wcześniej prawomocnie skazany za zabójstwo oraz sprawca zabójstwa funkcjonariusza publicznego popełnionego podczas lub w związku z pełnieniem przez nie- 
człowieka, poprzez przerwanie jego funkcji życiowych. Czynność ta może nastąpić na każdym etapie życia człowieka, tak w jego fazie początkowej jak i końcowej. Stąd też, za początek życia człowieka uznaje się „uzyskanie przez narodzonego człowieka zdolności do samodzielnego życia poza ciałem matki”. Z kolei za koniec życia uznaje się śmierć polegającą na ,trwałym i nieodwracalnym ustaniu czynności narządów niezbędnych dla życia” w szczególności ,nieodwracalne i całkowite ustanie czynności mózgu, a więc obumarcie mózgu”.

\subsection{Zabójstwo eutanatyczne}

Aspekt karny prawa do życia, obejmuje w ostatnim czasie także problematykę etyczną końcowej fazy życia osób ciężko lub nieuleczalnie chorych. Stąd też, przewidziane w systemach prawnych, zabójstwo na żądanie i pod wpływem współczucia - określa się mianem - zabójstwa eutanatycznego lub powszechnie: eutanazją.

Eutanazja (z j. greckiego - euthanasia „dobra śmierć”) oznacza przyspieszenie lub niezapobieganie śmierci w celu skrócenia cierpień chorego człowieka.

Prawo karne przewiduje podstawowy jej podział na: bierną (tzw. ortotanazję) i czynną (zabójstwo z litości lub eutanazja na żądanie) ${ }^{35}$. W doktrynie prawa uwzględnia się jeszcze podział na:

- eutanazję samobójczą (gdy chory samodzielnie podejmuje działania zabójcze);

- eutanazję samowolną (działanie bezpośrednio zabójcze podejmowane są bez wiedzy pacjenta i jego rodziny);

go obowiązków służbowych związanych z ochroną bezpieczeństwa ludzi lub ochroną bezpieczeństwa lub porządku publicznego.

$\S 4$. Kto zabija człowieka pod wpływem silnego wzburzenia usprawiedliwionego okolicznościami, podlega karze pozbawienia wolności od roku do lat 10 .

${ }^{35}$ Eutanazją mylnie bywała nazywana eksterminacja osób niepełnosprawnych przez nazistów podczas II wojny światowej (tzw. akcja T4). Szerzej na ten temat zob. L. KuBICKI, Zbrodnie wojenne w świetle prawa polskiego, Warszawa 1963; M. FLEMMING, J. WoJciechowska, Zbrodnie wojenne. Przestępstwa przeciwko pokojowi, państwu i obronności, Warszawa 1999. 
- eutanazję legalną (działanie bezpośrednio zabójcze podejmowane są bez wiedzy chorego i jego opiekunów, jednak z upoważnienia instytucjonalnego do podejmowania działań eutanatycznych);

- eutanazję dobrowolną (podjętą w oparciu o zezwolenie uprzednio i formalnie zadeklarowane).

Problematyka dopuszczalności eutanazji jest trudnym zagadnieniem etycznym. Nie bez znaczenia pozostaje konflikt racji, wynikający z różnych systemów wartości, jakimi kierują się strony. Przeciwnicy eutanazji, uznają życie za pierwsze i fundamentalne prawo i najwyższą wartość. Z kolei dla zwolenników ważniejsze jest uszanowanie woli chorego i jego ochrona przed cierpieniami związanymi z chorobą. Ta argumentacja powoduje coraz częstszą praktykę jej legalizacji (w Europie jako pierwsza Albania ją zalegalizowała w 1999 r. $)^{36}$.

W polskim Kodeksie karnym (art. 150 k.k. ${ }^{37}$ ) eutanazja czynna jest zabroniona. Jej efektem jest zabicie człowieka na jego żądanie pod wpływem współczucia dla niego. Sprawca jest zagrożony karą pozbawienia wolności od 3 miesięcy do 5 lat. Podstawą uzasadniającą łagodniejszą kwalifikację czynu zabójcy jest ustalenie: poczytalności chorego i zakres treści żądania (wyrażonego poważnie, a nie żartem lub będącego wynikiem załamania); oraz współczucia dla żądającego (uzasadnione np. chęcią ulżenia w cierpieniu). Ustawodawca przewidział możliwość zastosowania także nadzwyczajnego złagodzenia kary, a nawet możliwość odstąpienia od niej (uprawnienie to ma jedynie sąd). Warto także dodać, że ustawodawca w treści przepisu art. 150

${ }^{36}$ Eutanazja jest obecnie zalegalizowana w Albanii (od 1999 r.) Holandii (2002), Belgii (2002) Luksemburgu (2008) (w tym chorych dzieci), Japonii i amerykańskich stanach Teksas i Oregon, a do niedawna także w australijskim Terytorium Północnym. Ponadto w Szwajcarii oraz w Niemczech. Warto dodać, że 25 czerwca 2010 r. Niemiecki Trybunał Federalny wydał orzeczenie z którego wynika, że wspomagane samobójstwo jest legalne, jeśli pacjent wyraźnie zażyczył sobie zakończenia sztucznego podtrzymywania przy życiu. Trybunał podkreślił, że nadal nielegalna pozostaje aktywna pomoc w samobójstwie.

${ }^{37}$ Art. 150. § 1 . Kto zabija człowieka na jego żądanie i pod wpływem współczucia dla niego, podlega karze pozbawienia wolności od 3 miesięcy do lat 5.

$\S 2$. W wyjątkowych wypadkach sąd może zastosować nadzwyczajne złagodzenie kary, a nawet odstąpić od jej wymierzenia. 
k.k. nie wymaga wprost aby osoba żądająca zabójstwa eutanatycznego była śmiertelne chora, jednak wymóg taki wprowadza orzecznictwo ${ }^{38}$.

Dość specyficznym typem przestępstwa związanego $\mathrm{z}$ eutanazją jest pomoc do samobójstwa (art. 151 k.k. ${ }^{39}$ ), który obejmuje także tzw. eutanatyczną pomoc do samobójstwa, czyli ułatwienie osobie śmiertelnie chorej samobójstwa.

\section{Podsumowanie}

Prawo do życia od poczęcia do naturalnej śmierci, najwyżej i bez żadnych trudności interpretacyjnych przyjmuje Kościół katolicki, który prawo człowieka do życia uznaje za „pierwsze i fundamentalne prawo, za korzeń i źródło każdego innego prawa” ${ }^{40}$. Dla którego „istota ludzka powinna być szanowana i traktowana tak, jak osoba od chwili jej poczęcia, a więc od tego momentu należy przyznać jej prawa osoby, a między nimi na pierwszym miejscu nienaruszalne prawo każdej niewinnej istoty do życia" ${ }^{\text {"11 }}$. Zgodnie z nauczaniem Jana Pawła II „niezbywalne prawa osoby winny być uznawane i szanowane przez społeczeństwo cywilne i władzę polityczną. Owe prawa człowieka nie zależą ani od poszczególnych jednostek, ani od rodziców, ani nie są przywilejem pochodzącym od społeczeństwa lub państwa. Tkwią one w naturze ludzkiej i są ściśle związane z osobą na mocy aktu stwórczego, od którego osoba bierze swój początek. Wśród tych podstawowych praw należy wymienić (...) prawo do życia i integralności fizycznej każdej istoty ludzkiej od chwili poczęcia do naturalnej śmierci”.

${ }^{38}$ Szerzej zob. K. Daszkiewicz, Przestęstwa przeciwko życiu i zdrowiu. Rozdziat XIX k.k. Komentarz, Warszawa 2000; A. WĄsEK (red.), Kodeks karny. Część szczegól$n a$, t. I (art. 117-221), Warszawa 2006; A. MAREK, Kodeks karny. Komentarz, Warszawa 2004.

${ }^{39}$ Art. 151. Kto namową lub przez udzielenie pomocy doprowadza człowieka do targnięcia się na własne życie, podlega karze pozbawienia wolności od 3 miesięcy do lat 5 .

${ }^{40}$ JAN PaweŁ II, O cierpieniu. Wypowiedzi Ojca Świętego do chorych i pracowników stużby zdrowia (1978-1982), Warszawa 1985, s. 241.

${ }^{41}$ Zgodnie z Instrukcją Kongregacji Nauki Wiary. 
Wartość życia podkreśla również prawodawca polski, jednak każdorazowo umniejszając bezwzględny jego zakres, poprzez ustawowe kompromisy i relatywizację prawa. W konsekwencji życie ludzkie stało się przedmiotem umowy i negocjacji, podlega rozporządzeniom nie tylko podmiotu zainteresowanego, ale i osób trzecich. Współczesny kierunek ewolucji prawa do życia wprost to prawo neguje, poprzez legalizację zabicia człowieka i ochronę sprawcy takiego przestępstwa. Odkąd dla prawa, szczególnie karnego, życie ludzkie stało się wartością względną, a społeczeństwo zaczęło opowiadać się za wyłączeniem prawnokarnej jego ochrony, ustawodawca podjął kroki umniejszania człowieczeństwa dla życia w jego początkowej i końcowej fazie.

Prawo powinno służyć człowiekowi i jego dobru. Dziś jednak nie nadąża ono za zmianami i postępem cywilizacji. Musi więc odrodzić się silna więź między prawem a etyką, ukierunkowana na podstawowe wartości moralne, niezależna od światopoglądu i zgodna z etycznymi granicami rozwoju.

\section{The right to life, its inviolability and indisposability. Penal law aspects}

Respecting human rights should be a standard and a normative value in any democratic state of law, based on properly functioning legislative and executive branches of government. The right to life, i.e. the right to existence from conception to natural death, is an essential human right and a fundamental value. It is a natural right that results from the inherent dignity of all human beings, regardless of their development stage and physical or emotional maturity. In its constitutional sense, it belongs to the category of personal rights and liberties. It is a fundamental right which cannot be waived and which enables one to exercise other rights and liberties (e.g. the right to identity, privacy or education).

Although the Polish legislator highlights the value of human life, it always limits its absolute nature, making the law relative by statutory compromises. As a consequence, human life has become subject to contracts, negotiations and dispositions - not only of the party concerned, but of third parties, too. The contemporary law is evolving towards negating the right to life by legalising homicide and protecting the perpetrators. Since human life became a relative value for the law, in particular, for the penal law, and since the so- 
ciety supported the exclusion of its legal protection, the legislator has taken measures aimed at limiting the right to life in its initial and final stages.

The law should serve the humankind and its wellbeing. Today, however, it is lagging behind the developments of civilisation. There is a need to restore the bond between law and ethics in order to preserve basic moral values, regardless of individual worldviews, and to set ethical limits to progress. 